\title{
What influences the progression of employment rights disputes?
}

\author{
Bernard Walker and R.T. Hamilton
}

\begin{abstract}
This study of employment rights disputes in New Zealand accessed all parties to 14 disputes. Despite a legislative requirement to preserve relationships, only three survived. Dispute type, interaction mode and the parties' relative influence affected outcomes. These findings have implications for managers and policy makers regarding alternative dispute resolution systems.
\end{abstract}

\section{Introduction}

Why are some employment rights disputes resolved at a low level while others progress to inevitable termination? This study provides new insights into the progression and resolution of such disputes. As alternative dispute resolution (ADR) systems spread through the USA, UK and beyond, there is a dearth of research on how these operate in practice (Ridley-Duff and Bennett, 2011). What little is known comes largely from disputes in unionised and public sector organisations, a line of research dominated by quantitative inquiry that has overlooked the employee perspective (Bennett, 2013). This qualitative study affords detailed insights into the employee experience of disputes.

The authors accessed all the parties involved in 14 individual-level employment disputes as they progressed into external mediation in New Zealand, having exhausted all within-organisation efforts to resolve them. The employment relationships were continuing at this point. Although the statutory intent of the Employment Relations Act 2000 is to establish procedures and institutions that support successful employment relationships (s143), only three relationships survived, typical of cases that reach mediation (McAndrew 2010; McAndrew, Moreton and Geare, 2004).

Our purpose is to explore the progression of employment rights disputes and not to evaluate the mediation process as such, although we do use data from the mediation 
events. The interplay of three previously under-emphasised factors: dispute type; interaction mode; and the ability of the employee and their representatives to influence the events, affected how disputes were resolved. These factors should feature in more grounded and dynamic models of grievance disputes.

The next section reviews the field to provide the context for our study. We then describe our methodology and the unique data to which we were allowed access. Analysis follows where we derive the key factors of dispute type, interaction mode, and employee influence. The analysis section culminates in a more detailed discussion of one case which gives insight into the relative importance of these factors. We then discuss these findings before concluding the paper with implications for managers and policy makers.

\section{The Context of Grievances and Dispute Resolution}

Individual-level disputes ${ }^{1}$ between employee and employer are an enduring aspect of human resource management (HRM). While many are resolved informally, an increasing number progress into external resolution procedures such as mediation. While these procedures seek to resolve grievances and preserve employment relationships, many end with termination. Effective resolution processes can benefit managers by resolving conflict, minimising worker discontent and reducing staff turnover (Boroff, 1991; Olson-Buchanan, 1997). These procedures also protect employees, facilitating early dispute resolution (Freeman and Medoff, 1985; Lewin, 2005). Recent decades have however seen marked increases in the volume of formal employment disputes, with applications in the UK more than trebling between 1988 and 1996 (Burgess et al, 2001). Similar trends have been observed in New Zealand (May et al, 2001; Shulruf et al, 2009) and North America (Lipsky et al, 2003: 54).

Grievances are stressful for managers and come with a range of costs including management time and direct financial expense (Woodhams, 2007). The topic is also politicised, with employer groups complaining of increasing costs, complexity, and opportunism, as employees allegedly pursue ill-founded claims (Gibbons, 2007; McAndrew

\footnotetext{
${ }^{11}$ The term 'grievances' is used in a variety of ways, sometimes referring only to union procedures, but other times for both union and non-union procedures. The current discussion adopts the broader concept covering union and non-union situations, as well as other formal dispute resolution systems outside of North America which use terms such as individual-level employment rights disputes.
} 
et al, 2004; Shulruf et al, 2009). Organisations and governments have sought to improve the effectiveness of grievance procedures and contain the growth of formal claims (Antcliff and Saundry, 2009). The measures include promoting ADR methods (Budd and Colvin, 2008; Lipsky et al, 2003), and seeking to introduce low-level, early resolution mechanisms.

Previous research has typically used large datasets to explain grievance initiation, employee responses, grievance processing, and outcomes. This has explored variables such as grievant, workforce and workplace characteristics (Knight and Latreille, 2000a; Lewin, 1999), stage of settlement (Knight and Latreille, 2000b), representation (Antcliff and Saundry, 2009; McAndrew, 1999), and enterprise size (Saridakis et al, 2008; Woodhams, 2007), yet many areas remain ill-defined (Lewin, 2005). Another long-standing line of research has evolved from Hirschman's (1970) loyalty-voice-exit model (Lewin and Petersen, 1999; Luchak, 2003; Olson-Buchanan and Boswell, 2002). This frames grievances in terms of a single filing decision and most often in the North American context (Lewin, 2004: 402403). There are significant gaps in the research concerning aspects such as the role of other parties and other jurisdictions (Walker and Hamilton, 2011). This study reframes disputes as involving a progression of stages and a number of parties. The findings highlight three factors overlooked in the grievance literature, pointing to the need to expand the models of grievances and integrate this literature with other established lines of research into workplace conflict (Friedman et al, 2000; Frone, 2000).

New Zealand is a useful setting with its longstanding experience of resolving employment disputes. The broader principles of the New Zealand system are similar to those in other jurisdictions such as Australia and the UK (Antcliff and Saundry, 2009; Corby, 2000; Dickens and Hall, 2005; Gibbons 2007). These jurisdictions share a recent history of experimentation with legislation and policy that attempts to promote early resolution, encouraging employers and employees to resolve disputes within the workplace. These systems also offer external state-operated systems to facilitate prompt, low-level resolution of disputes that progress beyond the workplace.

\section{$3 \quad$ Methodology}

Qualitative research designs are rare in the area of employment disputes (Ridley-Scott and Bennett, 2011: 119) due to of the confidentiality that surrounds the proceedings, and so the insights offered here are valuable (Bingham, 2007; Bingham and Chachere, 1999; Denison 
and Corby, 2005; Lewin, 1999). The authors accessed all participants in fourteen disputes entering the external mediation stage, having exhausted all within-organisation processes. The gains from this approach were significant in terms of the comprehensive nature of the data and the multi-party perspective on the progression of disputes. Cases were selected to provide variation in terms of public versus private sector, and organisation size, although this was tempered by the practical difficulties of locating cases where all parties agreed to participate. Mediators and representatives affirmed that the resulting group of cases selected was representative of the range of disputes coming to them at that time. We cannot claim that this sample of 14 cases is fully representative of firm size or industry sectors in New Zealand but does encompass public and private organisations with employment size ranging from 24 to 6,000 for the organisation and from 9 to 550 for the geographic unit, e.g., retail shop or bank branch, in which the dispute arose. Details of the sample are in Table 1.

\section{Insert Table 1 here}

Fourteen has been suggested as the maximum number of cases for this type of research, with the present study involving over seventy in-depth interviews (Miles and Huberman, 1994: 31). The cases were all ongoing, with parties still in an employment relationship when they agreed to participate in this study. These were not serial disputants. This was the first formal dispute process for all but one of the employees, and none had a history of formal grievances with previous employers. There were no first-year employees, and over $70 \%$ had been with the employer for five or more years.

Entry into external mediation ensured a neutral venue and the capture of valuable real-time data, minimising retrospective sense-making (Harrison, 2003: 312). The data came from in-depth interviews, observations, and written documentation that triangulated each other (Eisenhardt, 1989a; Guba and Lincoln, 1994; Yin, 2003). Semi-structured interviews were conducted with employees, employers, representatives, and mediators. These were audio recorded and transcribed. Final follow-up contact with the interviewees occurred approximately one month after the mediation. All the mediation occurred through the statefunded mediation service, where one of the authors attended the mediation sessions as an observer. Written documentation, including pre-mediation exchanges, submissions prepared for mediation, and employers' internal dispute procedures, was also made available. 
Data analysis followed Eisenhardt (1989a; 1989b) as advocated by Lee et al (1999: 169-170). Within-case analysis created a summary of the dynamics of each dispute. This identified critical points and key influences in a dispute's progression, with the resulting information presented in narrative and diagrammatic forms. The second stage involved crosscase analysis, searching for meaningful patterns across the fourteen cases. NVivo analysis of the full interview transcripts confirmed the validity of the preliminary codes. This allowed further refinement from constant comparison between the emergent constructs and the data, leading to a final set of codes. The relationships between the codes were defined and higherlevel constructs identified. We also applied Miles and Huberman’s (1994) tabular approach to confirm patterns emerging from the coded narrative.

\section{$4 \quad$ Analysis}

There was a typical pattern of progression throughout disputes. Usually, an employee commenced by attempting low-level approaches such as discussing problems with their immediate supervisor or line manager. If this did not succeed, the employee may have then attempted formal or informal avenues if these existed within the organisation, and/or engaged external support from a trade union or other representative. If these within-organisation attempts also proved to be unsuccessful, the employee finally resorted to forums such as external mediation.

Eleven of the 14 disputes ended in termination of employment. Of those, nine involved settlements for termination reached at mediation; in the other two cases, by the time of follow-up one month after mediation, one had left the employer and the other had resigned but not yet departed at the time of the last contact. From the perspective of these eleven employees, the dissolution of their employment was non-consensual. Employees originally initiated the dispute resolution procedures in the hope that this would resolve the problems they were encountering and allow them to continue in jobs that they valued. Their goal was to solve the work-related problems and remain with their employer, according to our interviews. Those problems were not resolved though, and the employees felt that this failure created an untenable situation where continuance of the relationship was impractical. While in theory they had the option of proceeding to adjudication at the Employment Relations Authority (a quasi-first tier labour court), in reality, the financial, emotional, and relational costs meant that this was not feasible, and so the employees therefore reluctantly reached a settlement 
around their departure, as the best of a bad situation (Chen Palmer 2012). In contrast, with the remaining three cases, employment continued after the time of mediation, although the study did not track their longer term, post-mediation status.

The interplay among three factors influenced how the various disputes progressed: dispute type; how the parties interact; and the parties' relative influence. While each of the factors has its own effects, they also combined to influence disputes.

\subsection{Dispute Type}

The grievance literature does not distinguish different types of dispute and lacks an agreed typology. The construct of Dispute Type that emerged in this study seeks to characterise the dispute in terms of the underlying nature of the issue, similar to the longstanding distinctions between person and task-related conflict within the conflict literature (e.g. Frone, 2000). Three distinct types of disputes emerged, viz., interpersonal conflict; company decision; and interpretation, and these are explained here:

\section{$\underline{\text { Interpersonal conflict (IPC) }}$}

There was a personality thing here. And anyway, and also I had huge support from my other colleagues in the branch because they could see... singled out by $X$ and she picked on me and... they just kept telling me, go (Employee, Repbank)

This employee was based is a suburban branch with nine staff. Such disputes are relational and personalised, with conflict centred on the relationship between the employee and a specific other person. While conflict theory proposes that interpersonal elements can develop as a dispute escalates (Pruitt and Kim, 2004; Folger et al 2008), interpersonal conflict cases included situations where the conflict was present from the outset as a central and enduring aspect of the dispute:

So we had a new fashion manager come in. I had heard a lot about this fashion manager. None of it was positive - so yeah - I was quite apprehensive when she came in. She took an instant dislike to me...Told me she didn't like me. Told me [company] would be better off without me. (Employee, Retail) 
All the Interpersonal Conflict disputes in this study involved critical relationships with a direct line manager. The combined effects of proximity and reporting relationships meant that the manager had considerable influence over the employee's daily experience. The employee in Copier saw the events as part of a deliberate strategy by the manager who targeted him, making their conflict inescapable:

Yeah it was wrong and that was part of it and I thought I don't need this. I don't have to take that. That was part of it. I sort of thought, I don't need it. But if I'd stayed, I don't think I would have got away with it. I don't think I would have escaped him. (Employee, Copier)

\section{Company decision (CD)}

Company Decision disputes are about the application of an agreed policy to the situation of an individual employee. The issues were not personalised but involved the organisation and the employee:

Not that [manager] and I were at war, because I wasn't at war with [manager], I was at war with the [organisation] (Employee, Corg-A)

There were two variants within this type of dispute, depending on prior history. Such disputes could either be a single issue with no prior history, or part of a cumulative series of unsatisfactory interactions between the parties. The case of Corg A illustrates the single-issue variant with no prior history of disputes, whereas cases such as Corg B involved earlier disputes that had not yet been resolved satisfactorily from the employee perspective:

I felt quite strongly about not wanting to go back to work. Not having anything left. No energy, no nothing to try and start again. Because I've done it so many times before..... I didn't have confidence and it was unlikely that anything that they could say at mediation would restore that confidence. It's got to be by deed you know. It has to bethe proof's in the actions. (Employee, Corg B)

The final move to external mediation occurred when the employee had been unable to resolve earlier disputes within the organisation. The cumulative effect of these disputes eroded the employment relationship, particularly the employee's trust in management: 
I've been here for ten years and you know, when they - you know - mediate for five cents

an hour - I said I've had enough. You know -it just all piles up and they treat their staff like rubbish and I just had enough of it. (Employee, Movers)

\section{Interpretation (INT)}

Interpretation disputes concern a rule associated with the employment contract. Although there is an individual grievance, such disputes are effectively between the employer and the union or a collective group of employees. The issue is not personalised, but is about defining the rule rather than debating the application. The case of Blubank illustrates this, with both sides seeking to define the rules on whether company staff had priority over agency workers for vacant positions:

...and X said 'I will go to our lawyers' - the bank's lawyers - about this, and see what they say. The bank's lawyer said, we consider that because he's worked in the branch he can get the job - yeah - that is our ruling. So they came back and they said to me that he did have the job - and I said I believe that he can't have the job over me, and he said no, well, our rulings say that he can. (Employee, Blubank)

Similarly, Fleet involved a broad question of whether locally agreed protocols about relocating staff were binding:

What it was - it was bigger than the transfer, it was the fact I wasn't recognising local agreements. That's what got them. As soon as I said that, everything changes. Everything changed when I said that I don't recognise any local agreements...And that's why the whole fight came about. (Manager, Fleet)

The various forms of Dispute Type were associated with differing degrees of relationship damage and this presaged their differing trajectories and outcomes, especially the chances of achieving resolution and continuing the employment relationship. Three elements contributed to the overall damage: the criticality of the relationship, the costs experienced, and the extent to which the employment experience is affected.

The extent of damage in Interpersonal and cumulative Company Decision disputes meant that these had low prospects of restoration. Interpersonal Conflict involving a critical relationship between an employee and their immediate supervisor could rapidly generate high personal costs for employees. These disputes had a strong negative influence on the 
employee's daily experience of work, adversely affecting their overall relationship with the organisation. As these disputes progressed, the increasing costs for employees included deteriorating health and well-being, adverse effects on their family, and the erosion of trust in the employer. These costs, and the likelihood that they would continue into the future if the problems were not resolved, became so significant that they outweighed the benefits of the employment relationship, forcing the employee to accept termination:

Everybody that I know that's left [organisation] - they always say, they'll never go back, - they don't worry about the money. You know, they say their health is better, their relationships are better, they are sleeping and eating and they feel healthy. They feel normal. (Employee, Gamma)

I wanted to continue working there but with the new management ... the working relationship had broken down, the trust and the confidence. At that stage, I basically lost trust and confidence in the employer to do the right thing. (Employee, Waste)

A similar pervasive effect on the employment relationship occurred with cumulative Company Decision (CD) disputes. These however were not centred on critical relationships, and so the rate of decline was slower. In contrast, single Company Decision and Interpretation disputes did not involve damage to critical relationships, and so had better prospects for resolution. With CD single-issue disputes, only one facet of the employee's role was under scrutiny and their daily experience of work was unaffected. Similarly, Interpretation disputes affected only one aspect of the role and the disagreement was typically with a remote corporate office management, rather than involving a critical local relationship. This pattern echoes findings from the conflict literature, where interpersonal conflict, particularly with one's supervisor, has been associated with relational changes expressed in turnover intent and antagonism. These factors suggest that even conflict involving colleagues and persons of equal status can also have strong, negative effects on employment where these involve close working relationships (Friedman et al, 2000; Frone, 2000; Jehn, 1995; Spector and Jex, 1998).

Within the grievance literature however, the links between dispute type and their resolution have been ill-defined (Bemmels and Foley, 1996; Klaas, 1989; Lewin, 1999). Boswell and Olson Buchanan (2004) did distinguish between personalised mistreatment, concerning discretionary actions of an individual such as a supervisor, and policy-related mistreatment, involving a dispute over an organisational procedure or the 
administration of policy. Consistent with our proposition, they found that personalised mistreatment was associated with higher work withdrawal, compared to policy-related mistreatment. The full consequences of Dispute Type become more evident when viewed in conjunction with the other two factors, mode of interaction and influence.

\subsection{Interaction}

Each party employs a sequence of strategies and our findings highlight both the progression of these changes as well as the consequences of the strategies. To classify the strategies, we utilised Pruitt and Kim’s (2004) Dual Concern model as the framework. The dimensions of "self-concern” and “other concern” provide four possible strategies: contending, problemsolving, yielding, and avoiding. The most commonly observed strategies

were contending, when parties and their representatives attempt to resolve a dispute on their own terms without regard to the other side's interests, and problem-solving, identifying the issues dividing the parties and finding a solution which acknowledges the interests of both sides. Yielding occurred if employees reached a compromise deal as part of the termination of the relationship. ${ }^{2}$

The mode of interaction could change as the dispute progressed. A party's own approach could change, for example when they brought in an external third party as their representative; a problem-solving employee could engage a representative who would then conduct the events using a contending approach. The mode was also interdependent. In the initial exchanges, one party could adopt a problem solving approach, while the other was contending. If both sides used a contending approach, their interaction could be termed “mutual contending”. In contrast, a “mutual problem-solving” approach can produce outcomes satisfying both parties - but this can occur only in the less common situation where both sides maintain this same, common approach. When one party utilises a problem-solving strategy while the other party utilises a contending strategy, then the problem-solving party changes to mirror the contending strategy of the other party. This causes the overall interaction to become mutual contending, escalating the dispute and undermining the resolution process. Consequently mutual problem-solving becomes a less frequent mode and instead mutual contending dominates with negative effects on the relationship. In Retail the

\footnotetext{
${ }^{2}$ Avoiding was generally not a significant component in this part of sequences as it was usually a temporary stage where the employee tolerated a situation for a limited time, before taking action to attempt to address it.
} 
HR advisor sought initially to solve the problem and retain the employee, but when their interaction became strongly contending, this was abandoned:

I didn't go down there with that idea, to provide a monetary settlement. But after those kinds of outbursts [in mediation] .."you're a liar” ..there was no way we were going to be able to get $X$ back into that store...(HR Advisor, Retail)

The evolution of these approaches is in Table 2. In nine disputes, the initial intent of one party differed from that in the final interaction.

\section{Insert Table 2}

The full significance of Interaction becomes more evident however when it is seen in conjunction with Influence. The dynamic progression of the disputes typically saw them evolve into situations of "mutual contending”. In that type of interaction, the chances of achieving mutually beneficial outcomes diminished and the dispute was instead transformed into a win-lose struggle where one party's interests dominated at the expense of the other. In this situation, it was the employer's preferences that prevailed and the employee was unable to effect changes that could resolve the problems affecting their employment.

Interaction is interwoven with Influence, with Influence determining the outcome that results with specific Interaction types.

\subsection{Influence}

I am a fighter - I don't like being treated unjustly but it gets to the point when you think you just can't fight people - they hold all the cards. That's what made this decision to take the settlement. (Employee, Gamma)

ADR systems typically assume disputes to be misunderstandings that can be resolved, rather than contests between employees and employers (Van Gramberg, 2000; Van Gramberg and Menzies, 2005; Van Gramberg, 2006). Employment rights disputes, particularly when they form mutual contending interactions, become situations where the outcome depends on which party can muster the most influence. The employee's influence was found to come from three sources: the individual self; sources external to the organisation; and the employer's internal processes. 


\section{$\underline{\text { Individual self }}$}

An employee's skills, the importance of their role, their contacts, and their resources, including financial resources, can convert into influence for an individual. An employee with valuable, hard-to-replace skills is likely to have a greater ability to protect their own interests during a dispute. Similarly, an employee with experience, skills and knowledge related to disputes and legal issues will also have greater ability to defend their interests and achieve their desired outcomes. Cases such as Repbank illustrate low influence situations. The employee worked as a bank teller when there had been numerous redundancies. Their skills were not highly valued and the individual had very limited resources or experience in dealing with employment disputes. The employer had little dependence on this employee and the employee had little ability to influence the situation affecting their employment.

\section{$\underline{\text { External }}$}

The external-based sources involve the added influence available to a party from outside the organisation, for example getting legal representation or involving a trade union. In Blubank, senior union officials became actively involved, dealing directly with the company's senior management. In contrast, Corg B illustrates the low influence of an employee acting without external representation. The legal protections and support offered by industrial relations legislation can also augment the influence of parties in dispute, especially the employee. The effect of external intervention varied depending on the nature of the disputes but, more so, on the attitude of the new external party (Walker and Hamilton, 2012). Positive effects came when collaboration and problem-solving continued to characterise the resolution process. Negative effects such as polarisation, contending and position-taking were more common when lawyers or others trained in the adversarial tradition, were introduced (see Clark, 2012: 177).

\section{Organisational}

Organisational processes, in contrast, are within the employer's control and afford the employee some influence within the organisation to address perceived wrongs. For this to be meaningful however, these processes need to be seen as "safe”, “credible” and "effective” by employees. "Safe” means employees believe they will not suffer retribution from management, “credible” requires procedures that are objective, while "effective” systems are 
capable of actually producing the desired outcomes (Blancero and Dyer, 1996; Colvin, 2003; Harlos, 2001).

Such within-organisation systems operated to support the employee in the Corg A case. The procedures were regarded as safe because they used staff from outside the region who were perceived as unbiased, and avoided the risk of employer retribution. The process was perceived as credible and fair even when the outcome was unfavourable to the employee, and it was effective as it had the potential to reach decisions that resolved the problems affecting employees. In other cases, employees perceived that procedures were ineffective in addressing their complaints and so chose to avoid them. Repbank illustrates such low organisational level influence, where the employee attempted to use the internal appeal procedures but found the senior manager acted in a biased, predetermined manner and colluded with the front-line supervisor who was at the centre of the interpersonal conflict. This denied the employee sufficient influence to resolve the problem and only increased the antagonism between the employee and management:

that's when [supervisor]'s manager came in... And so [senior manager] came and had a meeting with me and she acknowledged there must have been a problem with - between [supervisor] and I. So then she said to me, why didn't you come - why hadn't I brought this problem up to her you know, through the year. And I told her that I was frightened, that I didn't feel that they would believe me. (Employee, Repbank)

Internal processes need to allow employees a fair and reasonable means to resolve contentious issues. Without this, the employee is likely to resort to external representation and so escalate the dispute. The overall progression of disputes becomes a dynamic, one driven by the notion of seeking influence sufficient to remedy the problem (Walker and Hamilton, 2012). The final resort to external mediation was a quest to gain enough influence to resolve disputes.

Such escalation was counterproductive for the employee though. Each attempt by the employee to gain more influence prompted the employer to respond in kind, so escalating the dispute. This change brought contending interactions and the party with the greatest influence would win (Bacharach and Lawler 1981; Kim et al., 2005). The employer had the greater influence - they could choose whether to remedy the perceived problem and retain the employee, or to make no concessions: 
Everyone kept saying, you're so strong, you're so strong - but if you don't fight, no-one else is going to do it for you. But, knowing the powers that be I was never ever going to win, when you look at it. (Employee, Repbank)

Company representatives spoke openly of how they held the upper hand, and if they chose to push for a negotiated departure, the financial cost was minor to achieve their preferred outcome:

But our strategy is yeah we don't want union presence here. So for them to lose a top delegate, that was $\mathrm{OK}$ with us. She had influence and we were quite prepared to pay the price to see her go. (HR Manager, Gamma)

In summary, three factors - dispute type, interaction, and influence - accounted for the progression of disputes, moving them towards either resolution or the escalation that intensifies conflict. Table 2 provides an overview of all cases in terms of these key factors. The patterns in Table 2 reveal combinations of factors associated with either termination or continuation of employment. The combination of either Interpersonal (IPC) or cumulative Company Decision (CD) dispute types, with Contending interaction and low employee Influence, proved a toxic combination for relationships, provoking rapid and irreversible deterioration of the relationship. Of the fourteen cases, eight had this combination and all were terminated either at mediation or in the days immediately following. The three cases of maintained employment involved interpretation (INT) disputes or single Company Decision disputes. When those cases reached mediation, personal relationships had not deteriorated significantly and could continue. These dispute types occurred in combination with problem solving interactions and higher employee influence at the outset and hence less escalation.

\section{The case of News Ltd}

The News case elaborates the model. This was an Interpersonal dispute but one involving a problem-solving interaction and high employee influence which, nevertheless, also ended with the termination of employment. The News employee had a successful international background in senior, specialist roles and was a senior manager at News. He possessed a 
high level of individual influence by virtue of his role, skills and experience. There was conflict however in the critical working relationship with the owner/manager and this escalated, causing significant problems which were not resolved within the organisation:

I'd rebuilt [organisation] and we were really starting to cook with gas, but against all that, I found the meetings with him to be really awful... it was just like, you felt demoralised. (Employee, News)

I'd say our personal relationship soured ... when I had a management team meeting...I would suggest it was clear that we were not getting on that well... Our regular meetings became more formal - it was very much xyz, tick cross, tick cross type of thing. You know - financials yep, okay. But we knew ourselves that things were deteriorating. (Employer, News)

When the employer made moves to attempt to summarily terminate the relationship without due process, the employee sought external influence by hiring an experienced employment lawyer. The employer also engaged a similar lawyer, and the two representatives developed a mutual problem-solving interaction. Although the mediator attempted to explore avenues for resolving the problems, the employer was unyielding in his stance that the relationship could not be restored, and thus left termination as the only option. The News case has two of the three factors associated with maintaining employment - high employee influence and a problem-solving interaction. Despite this, the dispute ends with termination. For the employee this involved a reluctant end to a role he largely enjoyed, driven by the implications of the personalised nature of the dispute:

..so it was a sense of relief in a way cause - I'll never have to sit down to a one-on-one with this guy... you know maybe I have done some things wrong in my time here but I think the problem lies with him. (Employee, News)

So it was - it was okay [employee name], this isn't working, I'm sorry, we've got to bring this to an end. It really was as blunt as that. (Employer, News)

News illustrates the dominant influence that Dispute Type can have. For parties involved in Interpersonal disputes, the move to mediation was the final step towards termination, irrespective of the influence of the employee can attempt or the nature of the interaction. 


\section{$5 \quad$ Discussion}

These findings raise questions regarding the resolution of employment rights disputes. The first concerns the effectiveness of official grievance procedures. Initially, such procedures were framed as a "judicial-type” appeal mechanism for employees to "protest and possibly to redress unfair or incorrect decisions” (Freeman and Medoff, 1985: 104; Lipsky et al, 2003). Over time, grievance procedures came to be seen as a means for workers to address the deterioration of their employment relationships (Lewin, 2005). More recently, with ADR options such as mediation, the onus has moved to not only resolving but also preventing disputes from developing or progressing to traditional litigation (Lipsky et al, 2003).

The cases studied involved numerous factors that should suggest a reasonable likelihood of maintaining the employment relationships. These were mainly long-serving employees who were seeking to resolve the issues and retain jobs that they valued, rather than win financial compensation. All the employment relationships were still intact when they entered mediation. Yet, in most cases, mediation was the prelude to termination.

Lewin (2005) notes that grievance procedures are generally invoked when a relationship has already deteriorated, and the literature suggests that grievance procedures themselves may produce additional deterioration (Walker and Hamilton, 2011). The present findings, particularly the pervasive influence of dispute type, along with the nexus of a contending interaction and low employee influence, go some way to explaining these outcomes, defining the process of decline that became endemic. While the contemporary emphasis is on restoring relationships, the pervasive influence of dispute type suggests that for interpersonal conflict and cumulative company-decision disputes, formal grievance procedures may become forums for settling departures, rather than restoration:

You don't want people forced back into a working relationship when quite obviously it's only doomed to failure... (Lawyer)

Nonetheless, with single Company Decision and Interpretation disputes, where the employment relationship has not significantly deteriorated, the outcomes were positive.

These findings have implications for within-organisation procedures and early intervention. The absence of effective organisation-level procedures is a catalyst for influence-seeking behaviour that escalates the dispute with destructive effect. These factors highlight the need for early intervention through suitable organisation-level 
processes. Giving employees more voice can foster a problem-solving interaction rather than a contending one, reducing the likelihood of third-party involvement and the escalation that this brings to the process. Recent policy has moved away from traditional formal approaches, seeking instead to decentralise dispute resolution to the organisation, on the conventional wisdom that resolution is more likely early and close to the point of origin of a dispute. Our findings suggest however that these matters are not straightforward and two factors undermine the outcomes of within-organisation resolution.

First, the potential for early resolution is significantly constrained by the dispute type. With Interpersonal disputes, the very rapid and pervasive relationship decline affords only a very small window for intervention. The opportunities for successful resolution and relationship preservation are limited if the parties are co-located and workgroups are small. While the early stages of cumulative Company Decision disputes may hold potential for early intervention, in the later stages where the relationship has already deteriorated and employees have lost trust, it is likely that employees will leave even if the current issue is resolved. In contrast, single Company Decision and Interpretation disputes involve longer timeframes and the impact of the dispute on relationships can remain low, offering greater opportunity for resolution. The second is the extent to which within-organisation procedures are "safe, credible and "effective" processes (Blancero and Dyer, 1996: 346). With the eleven termination cases, all but one of these organisations claimed to have procedures for dealing with disputes. There was however a major discrepancy between the existence of official written resolution procedures and their perception by employees as safe, credible and effective. Procedures often required employees to take unresolved issues to another local manager, invoking concerns about bias and the likelihood of retribution. Employees then either did not pursue matters or achieved unsatisfactory results, causing the dispute to escalate and proceed through to external mediation. In marked contrast, the cases of maintained relationships involved significantly greater organisational-level influence for employees. Those organisations had acceptable and effective dispute resolution procedures, with employees able to resolve disputes without escalation or feeling their employment was jeopardised.

\section{Conclusions}

We have framed employment disputes as dynamic sequences and identified three key factors that influence the progression and outcomes of disputes. Dispute type is not a new finding 
but the implications of this factor are significant, and clearly warn against any implicit assumption that disputes are homogeneous. The conflict literature recognises the importance of dispute type but this has not transferred to the mainstream grievance discourse. Interpersonal disputes have a low chance of resolution in a manner that restores the employment relationship, even in external mediation. The means and opportunity to resolve these disputes lies firmly within the organisation, through within-organisation approaches rather than legal forums. Moving them into external mediation and introducing representatives increases the likelihood of further escalating the disputes and eventual termination. This can make the mediation process one that simply formalises the separation between the parties rather than restoring relationships. As one experienced mediator commented:

Just how deep are the wounds with the parties... Is it that the wounds are just so deep that it's one of those things that some relations just get broken and that's it... no-one's going to fix something that is just broken (Mediator)

The construct of relative influence also offers additional insight. Although influence has also been overlooked in recent grievance literature, it is regaining prominence in the evaluation of newer forms of dispute resolution (Bingham, 2005), and forms an important element in contending settings. Adapting the Dual Concerns model Pruitt and Kim (2004) as part of the interaction mode captures the dynamics occurring in these disputes, particularly the consequences of Contending win-lose outcomes in an asymmetric relationship where one party is likely to have less influence. The interplay of these three factors forms distinct patterns, with the combination of Interpersonal conflict, Contending interactions, and low employee Influence generally leading to termination, despite attempts at mediation.

This has important implications for both managers and policy makers. In the cases studied, HRM staff had not been utilised early to resolve Interpersonal disputes, nor had they addressed the growing sense of grievance emerging from a long-running series of Company Decisions. Where these aspects are not resolved, strained relationships may move beyond repair. Within-organisation procedures need to afford employees adequate power to resolve matters without escalating the dispute (Boroff and Lewin, 1997: 58). The primary need is to understand the causes of such problems, identify possible patterns, and implement practices to prevent and manage future disputes. The influential role of dispute type necessitates a pragmatic re-evaluation of the limits of external mediation. Reframing grievances as a dynamic, evolving set of interactions provides a new perspective for research. Further 
research regarding these three factors may bridge the gap between the expectations and the reality of dispute resolution, moving towards improved systems that do not raise false expectations and can deliver better outcomes for employers and employees.

\section{References}

Antcliff, V. and R. Saundry (2009), 'Accompaniment, Workplace Representation and Disciplinary Outcomes in British Workplaces - Just a Formality?', British Journal of Industrial Relations, 47, 1, 100-21.

Bacharach, S. B. and E. J. Lawler (1981), 'Power and tactics in bargaining', Industrial and Labor Relations Review, 34, 2, 219-33.

Bemmels, B. and J. R. Foley (1996), 'Grievance procedure research: A review and theoretical recommendations', Journal of Management, 22 3, 359-84.

Bennett, T. (2013), 'Workplace mediation and the empowerment of disputants: rhetoric or reality, ' Industrial Relations Journal, 44, 2, 189-209.

Bingham, L. B. (2005), 'The Impacts of Alternative Dispute Resolution on Workplace Outcomes - Discussion, pages 131-133', Labor and Employment Relations Association Series Proceedings of the 57th Annual Meeting, pp. 131-3.

Bingham, L. B. (2007), 'Evaluation Dispute Resolution Programs: Traps for the Unwary', Labor and Employment Relations Association, Proceedings of the 59th Annual Meeting Labor and Employment Relations Association, Chicago, pp. 104-15.

Bingham, L. B. and D. R. Chachere (1999), 'Dispute resolution in employment: the need for research' in A. E. Eaton \& J. H. Keefe (eds), Employment Dispute Resolution and Worker Rights in the Changing Workplace Champaign, Illinois: Industrial Relations Research Association pp. 95-136.

Blancero, D. and L. Dyer (1996), 'Due process for non-union employees: the influence of system characteristics on fairness perceptions', Human Resource Management, 35, 3 343-59.

Boroff, K. E. (1991), 'Measuring the perceptions of the effectiveness of a workplace complaints procedure', Advances in Industrial and Labor Relations, 5, 207-33.

Boroff, K. E. and D. Lewin (1997), 'Loyalty, voice, and intent to exit a firm: a conceptual and empirical analysis', Industrial and Labor Relations Review, 51, 1 50-63.

Boswell, W. R. and J. B. Olson-Buchanan (2004), 'Experiencing mistreatment at work: the role of grievance filing, nature of mistreatment, and employee withdrawal', Academy of Management Journal, 47, 1, 12939.

Budd, J. W. and A. J. S. Colvin (2008), 'Improved metrics for workplace dispute resolution procedures: efficiency, equity, and voice', Industrial Relations, 47, 3 460-79.

Burgess, S., C. Propper, and D. Wilson (2001), Explaining the Growth in the Number of Applications to the Industrial Tribunals, 1972-1997, Centre for Market and Public Organisation, Department of Economics, University of Bristol, London. 
Chen, M., Palmer (2012), The Economics of Pursuing or Defending a Personal Grievance, Chen Palmer News, April 2012, http://www.chenpalmer.com/news/publications-and-presentations/the-economics-ofpursuing-or-defending-a-personal-grievance/, Downloaded 20 August 2014

Clark, B. (2012), Lawyers and Mediation, (Berlin: Springer)

Colvin, A. J. S. (2003), 'The dual transformation of workplace dispute resolution', Industrial Relations, 42, 4, 712-35.

Corby, S. (2000), 'Unfair dismissal disputes: a comparative study of Great Britain and New Zealand', Human Resource Management Journal, 10, 1, 79-92.

Dahl, R. (1957), 'The concept of power', Behavioural Sciences, 2:3, 201-15.

Denison, P. and S. Corby (2005), 'Images in the adversarial mirror: a study of the employment tribunal system in Britain', International Employment Relations Review, 11, 1/2, 21-36.

Dickens, L. and M. Hall (2005), Review of research into the impact of employment relations legislation, Department of Trade and Industry, London.

Eisenhardt, K. M. (1989a), 'Making fast strategic decisions in high-velocity environments', Academy of Management Journal, 32, 3, 543-76.

Eisenhardt, K. M. (1989b), 'Building Theories from Case Study Research', The Academy of Management Review, 14, 4, 532-50.

Folger, J.P, Poole, M.S., and Stutman, R.K. (2008) Working Through Conflict: Strategies for Relationships, Groups, and Organizations (6th Edition) Pearson, USA

Freeman, R. B. and Medoff, J. L. (1985), What do unions do? (New York: Basic Books).

Friedman, R. A., S. T. Tidd, S. C. Currall, and J.C. Tsai (2000), 'What goes around comes around: The impact of personal conflict style on work conflict and stress', International Journal of Conflict Management, 11, 1, 3256.

Frone, M. R. (2000), 'Interpersonal conflict at work and psychological outcomes: Testing a model among young workers ', Journal of Occupational Health Psychology, 5, 2, 246-55.

Gibbons, M. (2007) Better Dispute Resolution: A review of employment dispute resolution in Great Britain, (Lomdon: Department of Trade and Industry).

Guba, E., G. and Y. S. Lincoln (1994), 'Competing paradigms in qualitative research' in N. K. Denzin and Y. S. Lincoln (eds), The Handbook of Qualitative Research (Thousand Oaks, Calif: Sage) pp. 105-17.

Harlos, K. P. (2001), 'When organizational voice systems fail: more on the deaf ear syndrome and frustration effects', Journal of Applied Behavioral Science, 37, 3, 324-42.

Harrison, T., R. (2003), 'Victims, targets, protectors, and destroyers: using disputant accounts to develop a grounded taxonomy of disputant orientations', Conflict Resolution Quarterly, 20, 3, 307-29.

Hirschman, A. O. (1970), Exit, Voice, and Loyalty : Responses to Decline in Firms, Organizations, and States (Cambridge, Mass. : Harvard University Press).

Jehn, K. A. (1995), 'A multimethod examination of the benefits and detriments of intragroup conflict', Administrative Science Quarterly, 40, 2, 256-82.

Kim, P., H, R. L. Pinkley, and A. R. Fragale (2005), 'Power dynamics in negotiation', Academy of Managment Review, 30, 4, 799-822. 
Klaas, B. N. (1989), 'Determinants of grievance activity and the grievance system's impact on employee behavor: an integrative perspective', Academy of Management Review, 14, 3, 445-57.

Knight, K. G. and P. L. Latreille (2000a), 'Discipline, dismissals and complaints to Employment Tribunals', British Journal of Industrial Relations, 38, 4, 533-55.

Knight, K. G. and P. L. Latreille (2000b), 'How far do cases go? Resolution in industrial tribunal applications', The Manchester School, 68, 6, 723 - 44.

Lee, T., W., T. R. Mitchell, and C. J. Sablynski (1999), 'Qualitative Research in Organisational and Vocational Psychology, 1979-1999', Journal of Vocational Behaviour, 55, 161-87.

Lewin, D. (1999), 'Theoretical and empirical research on the grievance procedure and arbitration: a critical review' in A. E. Eaton \& J. H. O'Keefe (eds), Employment Dispute Resolution and Worker Rights in the Changing Workplace (Champaign, Illinois: Industrial Relations Research Association) pp. 187-218.

Lewin, D. (2004), 'Dispute resolution in the non-union organization: key empirical findings' in D. Sherwyn \& S. Estreicher (eds), Alternative Dispute Resolution in the Employment Arena: Proceedings of New York University Annual Conference Series(New York: Kluwer) pp. 379-403.

Lewin, D. (2005), 'Unionism and employment conflict resolution: rethinking collective voice and its consequences', Journal of Labor Research, XXVI, 2, 209-39.

Lewin, D. and R. B. Petersen (1999), 'Behavioral outcomes of grievance activity', Industrial Relations, 38, 4, 554-76.

Lipsky, D. B., R. L. Seeber, and R. D. Fincher (2003), Emerging Systems for Managing Workplace Conflict: Lessons from American Corporations for Managers and Dispute Resolution Professionals. (San Francisco: Jossey-Bass).

Luchak, A. A. (2003), 'What kind of voice do loyal employees use?', British Journal of Industrial Relations, 41, $1,115-34$.

May, R., P. Walsh, G. Thickett, and R. Harbridge, R. (2001), 'Unions and union members in New Zealand: Annual review for 2000', New Zealand Journal of Industrial Relations, 26, 3, 317-28.

McAndrew, I. (1999), 'Adjudication in the Employment Tribunal: some facts and figures on caseload and representation', New Zealand Journal of Industrial Relations, 24, 3, 365-82.

McAndrew, I. (2010), The Employment Institutions, in E. Rasmussen (ed.), Employment Relationships: Workers, Unions and Employers in New Zealand (Auckland NZ: Auckland University Press) pp. 74-93.

McAndrew, I., Moreton, J. and Geare, A. (2004), 'The employment institutions' in E. Rasmussen (ed.), Employment Relationships: New Zealand's Employment Relations Act (Auckland NZ: Auckland University Press) pp. 98-118.

Miles, M. B. and Huberman, M., A. (1994), Qualitative data analysis 2e, (Thousand Oaks, Calif: Sage).

Olson-Buchanan, J. B. (1997), 'To grieve or not to grieve: factors relating to voicing discontent in an organizational simulation', The International Journal of Conflict Management, 8, 2, 132-47.

Olson-Buchanan, J. B. and W. R. Boswell (2002), 'The role of employee loyalty and formality in voicing discontent', Journal of Applied Psychology, 87, 6, 1167-74.

Pruitt, D. G. and S. H. Kim (2004), Social conflict: escalation, stalemate and settlement 3e, (Boston: McGrawHill). 
Ridley-Duff, R. and A. Bennett (2011), 'Towards mediation: developing a theoterical framework to understand alternative dispute resolution', Industrial Relations Journal, 42, 2, 106-123.

Saridakis, G., S. G. Sukanya, P. Edwards, and D. J. Storey (2008), 'The impact of the enterprise size on employment tribunal incidents and outcomes: evidence from Britain', British Journal of Industrial Relations, 46, 3, 469-99.

Shulruf, B., B. Woodhams, C. Howard, J. Roopali, and B. Yee, (2009), "Grievance gravy train picking up speed': myths and reality around employment disputes in New Zealand', Journal of Industrial Relations, 51, 2, 24561.

Spector, P. E. and S. M. Jex (1998), 'Development of four self-report measures of job stressors and strain', Journal of Occupational Health Psychology, 3, 4, 35667.

Van Gramberg, B. (2000). Mediation, structural violence and industrial relations. Working Paper 5/2000. School of Management, Victoria University of Technology.

van Gramberg, B. (2006). Managing Workplace Conflict: Alternative Dispute Resolution in Australia. Sydney, Federation Press.

Van Gramberg, B. and J. Menzies (2005). Grievance procedures in organisations - why do they fail? Working Paper 12, 2005. School of Management, Victoria University, Australia.

Walker, B. and R. T. Hamilton (2011), 'Employee-employer grievances: a review', International Journal of Management Reviews, 13, 1, 40-58.

Walker, B. and R. T. Hamilton (2012), 'Representatives and employment rights disputes: What works and what doesn't', Journal of Industrial Relations, 54, 5, 596-611.

Woodhams, B. (2007) Employment Relationship Problems: Costs, Benefits and Choices, August 2007, (Wellington: Department of Labour).

Yin, R. K. (2003), Case Study Research: Design and Methods $3 e$ (Thousand Oaks, Calif. : Sage Publications). 
Table 1 Description of sample of organisations

\begin{tabular}{|c|c|c|c|c|}
\hline Case & Private I Public Sector & Industry & $\begin{array}{c}\text { Organisation } \\
\text { Total size }\end{array}$ & $\begin{array}{c}\text { Local } \\
\text { unit size }\end{array}$ \\
\hline ALARMS & Private & Security / protection & 24 & 24 \\
\hline COPIER & Private & Electronics & 285 & 28 \\
\hline GAMMA & Private & Service / hospitality & 550 & 550 \\
\hline REPBANK & Private & Banking & 6000 & 9 \\
\hline RETAIL & Private & Retail & 3500 & 70 \\
\hline NEWS & Private & Media & 100 & 100 \\
\hline WASTE & Public-Owned Trading & Waste & 150 & 150 \\
\hline ROAD & Private & Construction & 3000 & 400 \\
\hline CORG - B & Public & Law and legal services & 1,817 & 34 \\
\hline MOVERS & Private & Removals & 240 & 35 \\
\hline TERMINUS & Public-Owned Trading & Transport / tourism & 175 & 175 \\
\hline CORG- A & Public & Law and legal services & 1,817 & 11 \\
\hline BLUBANK & Private & Banking & 2243 & 15 \\
\hline FLEET & Public & Emergency services & 2100 & 160 \\
\hline
\end{tabular}


Table 2: Dispute profiles

\begin{tabular}{|c|c|c|c|c|c|}
\hline Case & Dispute type & $\begin{array}{c}\text { Initial } \\
\text { interaction }\end{array}$ & $\begin{array}{c}\text { Final } \\
\text { Interaction }\end{array}$ & $\begin{array}{l}\text { Employee } \\
\text { influence }\end{array}$ & Outcome \\
\hline ALARMS & $\begin{array}{c}\text { Interpersonal } \\
\text { conflict }\end{array}$ & $\begin{array}{c}\text { Problem-solving } \\
\text { x Employee }\end{array}$ & Contending & Low & $\begin{array}{c}\text { Terminated } \\
\text { (at mediation) }\end{array}$ \\
\hline BLUBANK & Interpretation & $\begin{array}{l}\text { Problem-solving } \\
\text { - Mutual }\end{array}$ & $\begin{array}{l}\text { Problem-solving } \\
\text { - Mutual }\end{array}$ & High & $\begin{array}{l}\text { Continuing } \\
\text { employment }\end{array}$ \\
\hline COPIER & $\begin{array}{c}\text { Interpersonal } \\
\text { conflict }\end{array}$ & $\begin{array}{l}\text { Problem-solving } \\
\text { x Employer }\end{array}$ & Contending & Low & $\begin{array}{c}\text { Terminated } \\
\text { (at mediation) }\end{array}$ \\
\hline CORG A & $\begin{array}{l}\text { Company } \\
\text { Decision } \\
\text { (Single) }\end{array}$ & $\begin{array}{c}\text { Problem-solving } \\
\text { - Mutual }\end{array}$ & Contending & High & $\begin{array}{l}\text { Continuing } \\
\text { employment }\end{array}$ \\
\hline CORG B & $\begin{array}{c}\text { Company } \\
\text { Decision } \\
\text { (cumulative) }\end{array}$ & $\begin{array}{l}\text { Problem-solving } \\
\text { x Employee }\end{array}$ & Problem-solving & Low & $\begin{array}{c}\text { Terminated } \\
\text { (at mediation) }\end{array}$ \\
\hline FLEET & Interpretation & $\begin{array}{c}\text { Problem-solving } \\
\text { - Mutual }\end{array}$ & Problem-solving & High & $\begin{array}{l}\text { Continuing } \\
\text { employment }\end{array}$ \\
\hline GAMMA & $\begin{array}{c}\text { Interpersonal } \\
\text { conflict }\end{array}$ & $\begin{array}{c}\text { Problem-solving } \\
\text { x Employee }\end{array}$ & Contending & Low & $\begin{array}{c}\text { Terminated } \\
\text { (at mediation) }\end{array}$ \\
\hline MOVERS & $\begin{array}{c}\text { Company } \\
\text { Decision } \\
\text { (cumulative) }\end{array}$ & $\begin{array}{l}\text { Problem-solving } \\
\text { x Employee }\end{array}$ & Contending & Low & $\begin{array}{c}\text { Terminated } \\
\text { (after mediation) }\end{array}$ \\
\hline NEWS & $\begin{array}{l}\text { Interpersonal } \\
\text { conflict }\end{array}$ & $\begin{array}{c}\text { Problem-solving } \\
\text { - Mutual }\end{array}$ & Problem-solving & High & $\begin{array}{c}\text { Terminated } \\
\text { (at mediation) }\end{array}$ \\
\hline REPBANK & $\begin{array}{l}\text { Interpersonal } \\
\text { conflict }\end{array}$ & $\begin{array}{l}\text { Problem-solving } \\
\text { x Employee }\end{array}$ & Contending & Low & $\begin{array}{c}\text { Terminated } \\
\text { (after mediation) }\end{array}$ \\
\hline RETAIL & $\begin{array}{l}\text { Interpersonal } \\
\text { conflict }\end{array}$ & $\begin{array}{l}\text { Problem-solving } \\
\text { x Employer }\end{array}$ & Contending & Low & $\begin{array}{c}\text { Terminated } \\
\text { (at mediation) }\end{array}$ \\
\hline ROAD & $\begin{array}{l}\text { Interpersonal } \\
\text { conflict }\end{array}$ & $\begin{array}{c}\text { Problem-solving } \\
\text { x Employer }\end{array}$ & Contending & Low & $\begin{array}{c}\text { Terminated } \\
\text { (at mediation) }\end{array}$ \\
\hline TERMINUS & $\begin{array}{c}\text { Company } \\
\text { Decision } \\
\text { (cumulative) }\end{array}$ & $\begin{array}{l}\text { Problem-solving } \\
\text { x Employee }\end{array}$ & Contending & Low & $\begin{array}{l}\text { Terminated (at } \\
\text { mediation) }\end{array}$ \\
\hline WASTE & $\begin{array}{c}\text { Company } \\
\text { Decision } \\
\text { (cumulative) }\end{array}$ & $\begin{array}{l}\text { Contending - } \\
\text { Mutual }\end{array}$ & Contending & Low & $\begin{array}{c}\text { Terminated } \\
\text { (at mediation) }\end{array}$ \\
\hline
\end{tabular}

